\title{
Study experience of Indian students and inter-racil relations at the University of Kwazulu-Natal
}

Oyewo Adetola Elizabeth

ollytola@yahoo.com

University of Kwazulu, Natal - Durban, África do Sul

\section{Samuel Uwenm Umoh} Samuno800@gmail.com University of Kwazulu, Natal - Durban, África do Sul

\begin{abstract}
Indian students occupy a prominent space in South African higher educational institutions and form part of a diverse student population. This is the result of a multiracial, democratic society; the imperatives of cross border migration; and globalization trends in higher education. This paper discusses the 'pull and push' factors that motivated Indian students to study at the University of KwaZulu-Natal (UKZN). The paper then examines inter-racial relations in terms of academic and social relationships among Indian students and other student populations at UKZN within the framework of the Allport social contact theory. Research methods for the study include focus groups and qualitative methods. Primary data was gathered through oral interviews from ten undergraduate Indian students at the Department of Tourism at the University of KwaZulu-Natal. The primary findings of the study are that Indian students prefer to gather together with their fellow Indian classmates
\end{abstract}




\section{INTRODUCTION}

Indian students are part of larger Indian community and descendants of migrantIndians.They are spread across various countries as Britain, USA, Canada, and South Africa. Indians resident in South Africa are referred to as 'Indians SouthAfrica'. Indians South Africa are estimated to about 1,300,000, making up of about 2.7\% of the South African population (Mukherji 2011).Quite a significant populations of Indians are located in Durban, Pietermaritzburg, Johannesburg and Cape Town. Durban, is considered as the largest Indian city outside India'(Mukherji 2011).According to the 2011 Census, 79.2 per cent of South Africans (41 million per cent) were Black Africans, 8.9 per cent were Colored (4.62 million), 8.9 per cent were white (4.59 million), 2.5 per cent were Indian or Asian (1.29 million) and about 0.2 per cent (280.4) were classified into another race. According to the Ministry of Overseas Indian Affairs (2012), Indiansconstitutes one of the second largest Diasporas in the world overseas after Chinese. Indians have diverse regional languages as Bodo, Dongri, Odia, Tamil, Sindil, Punjabi, Telugu, Santhali amongst others butofficial languageis Hindi. Some of their religions are Hinduism, Islam, Roman Catholicism, Protestantism, Zoroastrianism, Jainism, and Sikhism.

Race and ethnicity have been one of the distinguishing features of South Africa especially during European colonization.Interracial friendship is located within the context of race, ethnicity and language. Race has been part of crux of South African history, politics, society, culture, education and economy .Hall (1994) point out that 'cutaneo-chroma' also referred to asskin color is a salient features in any society, as it has effect on every aspect of life, including job placement, earnings, access to education opportunities and interpersonal relationship.Indian students are enrolledin almost all universities allover the world, although their proportion varies. They are in countries as Canada, USA, UK and other European countries (Open Door 2009).Choudaha (2014) observes that about 200,000 Indian students are enrolled outside their country and the second largest source of global mobile students. He explains further that nearly two out of Indian students enroll in STEM-related field such as sciences, technology, engineering, physical and earth sciences. In the USA universities, Indian students were estimated as 96,754 in 2012-13, and 94,563 in 2007-2008 (Choudaha 2014).

\section{RESEARCH OBJECTIVE}

The paper evolved on scarcity of literature on inter-racial friendship amongst Indian students and other race in South AfricaUniversities. The paper aims to:

i. To examine interracial friendship amongst Indian students and other race at the university of kwaZulu-Natal(UKZN)

ii. To identify and discuss UKZN as an institutional choice of study amongst Indian students

iii. To examine factorsthat affect interracialfriendship.

iv. To suggest how interracial relationship canbe fostered among Indianstudents and other students at UKZN. 


\section{DEFINING INTERRACIAL AND THE NEED FOR INTERRACIAL FRIENDSHIP}

South Africa is an ethnically diverse country in terms of mixture of different races, cultural identities, languages and ethnic bonds. Race and ethnicity was paramount during the apartheid era, when the government used it for political and racial purposes.Four official racial categories were identified as black, colored, white and Asian/Indian. Interracial friendship is associated with different terms as 'interracial contact' , 'intergroup , inter- ethnic', 'integration' 'casual versus intimate contact challenge'(Binikos and Rugunanan, 2015:Cinzia 2015; Gouws 2008;Goldstein 1994; Amir 1969).Amir (1969) and Goldstein (1994) use the term 'intimate interracial contact' and refer it as 'casual versus intimate contact challenge'. Interracial friendships also referred to as 'intergroup /interethnic friendship'(Cinzia 2009).Although racial discriminatory policies and segregation had been in place long before the beginning of apartheid in 1948. Cinzia (2009);Goldstein (1994);Amir (1969) explains that interracial relationship as close friendship does not necessarily involve sexual relations. Interracial relationship is an engagement, voluntary mingling betweenrace groupsand more than co-existence with others (Pattman2010; Gouws2008).Interracial relationship entails social contact and friendships, dating, marriage, sharing of intimate spaces, such as bathrooms and kitchensin residential places founded on positive attitudes(Pattman 2010 ;Gouws 2008).In this paper, we define interracial relationship as friendship between students of various physical and cultural features (in this case Indians students and other students outside their race).

\section{UNIVERSITIES AND INTERRACIAL FRIENDSHIP}

Schoolsare sites of identity, places where students draw conclusions about the kind of people they are, what the society has in storefor them, and what they can therefore hope for" (Steinitz and Solomon 1989:135). Universities are platform for social and cultural competencies vital for the formation and the support of intergroup friendships (Zirkel 2008). Morrow (2008) observes that South Africa universities were restructured in the 2000 s to create an environment of students socialization, based on non-racism and nondiscrimination, but still, race and class cleavages between (and within) institutions has not subdued nor improved(Morrow 2008). Binikos and Rugunanan (2015) argue that the pattern of interracial friendship in South Africa higher institutions after the restructuring did not eradicate race and class. The composition of aschool and school structure can either promote or mitigate interracial friendship (Cinzia 2009; Fischer 2008). There are many benefits that accrue to students and schools with multicultural setting. Students that attend multiracial schools, mature in environments in which contact with other race groups is frequent (Seekings 2008). Interracial Friendship is vital to reconstruction, development and reconciliation in South African society (Du Plessis 1999). Students involved in ethnically and racially heterogeneous school settings experience a positive attitude change, sense of personal growth, positive school culture and academic development (Mojapelo-Batka 2008; Zirkel 2008). Cinzia (2009) highlight positive intergroup attitudes, decreased racial prejudice, increase in common sense of identity and personal closeness as some of the benefits of interracial friendships (Troop 2007; Pettigrew 1998). Interracial 
friendships have positive effects on behavioral, social, affective domains and campus diversity (Fischer 2008;Cinzia 2009). Hunter and Elias (1999) found that students with at least one reciprocated high quality interracial friendship are more socially skilled, rated higher on a sociability measure, and participated in more diverse social networks than students without interracial friendships.

\section{UNIVERSITY OF KWAZULU-NATAL (UKZN)}

The University of KwaZulu-Natal (UKZN) has a sizeable number of Indian students. The University of KwaZulu-Natal (UKZN) was established on January 1, 2004 as a merger of the University of Natal and University of Durban, Westville. It has five campuses located in Durban, Westville, Pinetown, Howard, Pietermaritzburg and Kwazulu-Natal. The University of KwaZulu-Natal (UKZN) emerged as a result of mergers of advantaged 'historically white universities (HWUs) and disadvantaged 'historically black universities' (HBUs). The need for universities to be merged emanated from the need to overhaul the education system in terms of socialtransformation, equitableaccess, racially integrated system of education and correcting structural inequalities, primarily those of race and class, at a macro level of society (CHE 2000; Department of Education 1997).Prior to the restructuring, gross differences in teaching, student intake and outputs, curriculum, access to funds and other resourceswere common feature of higher institutions (CHE 2000). The merger resulted in re-arrangement of 36 racially divided institutions (colleges, technikons, universities) across the country, into 21 institutions ( Binikos and Rugunanan 2015; Morrow2008).

Historically, the Extension of University Act, Act no. 45 of 1959, was passed to put an end to black students attending white universities (mainly the universities of Cape Town and Witwatersrand). Non-white students that were removed from such universities were expected to attend separate tertiary institutions that the Apartheid Government had created for colored, black, and Asian students (Hayward 1989).This brought about the University of DurbanWestville now part of the University of KwaZulu-Natal, built with a Rand-forRand contribution from Indian South Africans and the government in the 1970s(Wikipedia 2015).According to 2011/ 2012 HEMIS databaseStatistics on Post-School Education and Training in South Africa, it stated that the University of KwaZulu-Natal (UKZN) is one of the top recipient of Indian students in South Africa's universities. In 2011 the number of Indian students was estimated at 11, 080 for contact students while distance students were 326 . In other higher institutions as Durban University of Technology;4,125; University of Witersrand;4,050,; University of Johannesburg; 2,299, UJ;2,299; and University of Pretoria ;2,023. According to Stumpf (2013) Indian, Asian and colored student enrolments has remained more or less the same. Furthermore, in 2000, the enrolments of Indian, Asian and Colored students was $7 \%$ and $5 \%$ respectively, in 2006 it was $7 \%$ and $7 \%$, and in $2011,6 \%$ and $6 \%$ respectively

\section{WHY INTERRACIAL RELATIONSHIP SEAMS DIFFICULT IN SOUTH AFRICA HIGHER INSTITUTIONS?} segregation still exists inpost-apartheid era (Chigumadzi 2015; Tredoux 
andFinchilescu 2007).It would be difficult understanding marred interracial friendship amongst Indian students and other race without understanding the historical foundation that watered it.Despite that the need and benefits of interracial relationship amongst students is vital in heterogeneous society. Arguably marred interracial relationship in South Africa is attributable to historical residual of the apartheid regime. A new multi-cultural South Africa, Indian and African communities are trying to overcome their batteredrelation, as mixed race relationships have been subjected to a range of deterrents (BBC 2011).Tatum (1997) observes that students tend to befriend same-race peer and self-segregate. Seekings (2008)Binikos and Rugunanan (2015) argues that South Africans continue to see themselves in the racial categories of the apartheid era, because these categories have served as the basis for post-apartheid 'redress' and retain cultural meaning in everyday life. They explain that higher institutions transformation occurred without the deconstruction of 'race', which still breed mutated race class divisions. In the course of inter-racial relationship, factors as linguistic and cultural barriers; anxiety and possibility of prejudice can mitigate friendship (Chigumadzi2015). At this juncture, it is pertinent to examine the historicalfactors affecting interracial relations in SouthAfrica. Foster and Finchilescu (1986) classify South Africa as a 'non-contact society' because the permissible contact was limited. Although it cannot be denied that there was interracial contact evident in hierarchical level such as boss-servant; bureaucratic such as state agent - supplicant.Such contact was oppressive, violent, threatening, anxiety-provoking, and exacerbated prejudice as this did not did not improve interracial relations(Foster and Finchilescu 1986; Stephan and Stephan 1985).Msimang (2015) in the concept of "coconuts"notethat interracial relationships are still problematic in South Africa.Msimang (2015) puts succinctly that ..."In the current state of South Africa, it is extremely difficult to have genuine relationships beyond race - there are too many inequalities that still exist and until whiteness is willing to confront itself, it will not be possible. Whiteness has to sacrifice itself at the altar of its privilege first...". The opportunities for racial interaction have been limited at university, by residential areas and schools, still segregated along racial lines, class and compatibility (Bhana 2014; Morrow2008). Historically, the various laws that was formulated during the apartheid regime from 1948-1994 is still affecting interracial relationship, and brought about unhealthy interracial relations between the different races in South Africa. Few of such laws include:

i. The Prohibition of Mixed Marriage Act, Act no. 55 of 1949. This law prohibited marriages between white people and people of other races, including Indian people(Hayward 1989).

ii. The Group Areas Act, Act no. 41 of 1950. The law forced physical separation between races by creating different residential areas for different races. In addition, this law also led to forced removals of people living in "wrong" areas (Hayward 1989).

iii. The Reservation of Separate Amenities Act, Act no. 49 of 1953, forced segregation in all public amenities, public buildings, and public transport with the aim of eliminating contact between whites and other races. "Europeans Only" and "Non-Europeans Only" signs were put up in order to enforce the act. The act stated that all public facilities that were provided for different races need not be equal (Hayward 1989). 
It is in recognition of this lacuna, that efforts at national level to restore interracial relation was advocated. Freedom fighters such as the Anglican Archbishop Desmond Tutu coined the phrase 'Rainbow Nation'. A rainbow nation at peace with itself and the world" (Manzo 1996:71). This statement was pronounced with an intention of declaring unity between tribes, racial groups and sexes.

Symbolically, the image of the 'Rainbow Nation', popularized by Archbishop Desmond Tutu in 1994 and often used to describe the post-apartheid South Africa. It has become an important symbols to promote the idea of a free, multiracial democratic society. Other symbols include the constitutional recognition of eleven official languages, the post-1994 flag and the country's unique hybrid national anthem combining the traditional African song Nkosi Sikelel' iAfrika with the apartheid-era .

\section{THEORY ON INTERRACIAL RELATIONSHIP}

Allport (1954) contact Hypothesis also known as 'intergroup contact theory' underpinned the theory for the paper. The theory is based on the tenets that interracial relationship is effective when there is cooperative activity between students. Students from diverse race should work on a problem, task and share a common goal. The task must be structured so that individual members of both groups are interdependent on each other to achieve commongoals (Brown and Hewstone 2005;Pettigrew 1998). In parallel line, prejudice may be reduced when there are equal status between majority and minority groups in the pursuit of common goals, sanction by the institutional supports such as law, custom or local atmosphere.The other conditions for optimal intergroup contact such as equal group status within the situation, common goals, intergroup cooperation and authority support are crucial. Through the sharing of intimate information, trust and familiarity are encouraged, and individuals are more likely to overcome perceived differences and see more similarity between one another. Pettigrew (1998) argue that contact alone is insufficient for inter racial relation but theneed for optimal interracial contact, optimal need adequate cross -group friendship to continue.

\section{RESEARCH METHOD}

The research is based on qualitative research method, based on observation and interviews during2014/2015 session. The questions covers themes on the following questions:

i. What is your perception in relation to other students outside their race?

ii. Are you comfortable been friends" with schoolmate different from your race?

iii. Are you comfortable been part of study group, sharing accommodation and dating schoolmate outside your race?

iv. What are the reasons for UKZN as an institutional choice of study?

v. How can interracial relationship be fostered among students in University? 


\section{PARTICIPANTS}

The participants comprised ten postgraduate Indian students at the Tourism Department. The participants were selected through snowball sampling method and within student networks such as UKZN student email portal.

\section{DEMOGRAPHIC PROFILES}

The demographics of the participantswere reflective, in terms of gender representations $50 \%$ male respondents and $50 \%$ femalerespondents.

- In terms of age bracket, they fall within the age bracket 20-32 years .

- Marital Status: Married( $n=4)$, single( $n=4)$

- Course level: Undergraduate $(n=6)$ Honours $(n=2)$, Masters $(n=2)$

- Mode of study: Full Time( $(n=8)$, Part Time $(n=2)$

\section{FINDINGS AND DISCUSSION}

The findings below are summarized and organized thematically to express the most salient conclusions. Summary of multiple choice options offered in the questionnaire.

- Participants agree that race do not matter during interracial friendship.

- linterracial friendship is more of compatibility, values than race, common interest, parental up bringing, prior friendship before entering university are crucial in friendship.

- They have friends from other racial groups. Friends from other race are pleasant and helpful.

- 'They are comfortable with "Being friends" with schoolmate different from their race, sharing accommodation, dating and participating in a study group with schoolmate outside their race.

- They agreed that they befriend people of different races. But majority of their friends are Indian, because there is no barriers of communication ,speak the same language, share and understand the same culture.

\section{UKZN AS INSTITUTIONAL CHOICE OF STUDY}

- UKZN is a prestigious institution where learning is facilitated in an excellent manner and a well known institution internationally.

- Proximity to family

- A student admitted thathe onceattended western cape university because he thought they had standard, but had to quit because of discrimination from Afrikaner students in form of attitude and language . 
The participants agreed on the common themes on fostering interracial relationship among students at University. These include;

- Explaining to students how to differentiate between seeing and been prejudice.

- Students working closely with each other through group tasks.

- Students should be exposed to positive role models of interracial groups

- Displaying posters of Mandela or Gandhi as these posters can make a difference as to how students view social groups to which these role models belong.

- Schools should encourage festivals and celebrations that emphasize the history, literature and cultural contributions of diverse groups in South Africa.

- School cultural integration whereby symposium, love feast and parade can strengthen interracial friendship.

- Institutions should promote racial inclusions by teaching diversity

- Support ethnic studies program about race is stimulated

- Participate in community project to reduce racial disparities in opportunities.

\section{CONCLUSION}

Quite a significant proportion of Indian student are in UKZN because of history of migration in Kwazulu-Natal. Indian students have different attitude towards interracial friendship based on personal reasons, and the kind of encounter with someone outside their racial group. School culture can also support or mitigate intergroup friendships. 


\section{REFERENCE}

"A History of Indian Settlement in KwaZulu-Natal". Kzn.org.za. Retrieved 2011-1106.

Allport G.1954.The Nature of prejudice, Cambridge , MA: Perseus Books.

Amir, Y. 1969. ' Contact hypothesis in ethnic relations: Psychological Bulletin'. 71,319-342

BBC(2011). 'Mixed Race Britain; How the World Got Mixed up'. [online] Available at www.bbc.co.uk/...mixed5.shtml

"BBC World Service | Bridgin the divide: Indians in South Africa". Bbc.co.uk. accessed on $20^{\text {th }}$ September 2015

Bhana, D. 2014 . ' Race matters and the emergence of class: Views from selected South African university students'. South African Journal of Higher Education 28(2): 355-367

Binikos, E. and Rugunanan, P.2015. 'Racial Integration among Students at the University of Johannesburg'.Journal of Sociology Soc Anth6(1): 45-63

Brown, R., and Hewstone, M.2005. 'An Integrative theory of intergroup contact'. InM.P.Zanna (Eds.,Advances in experimental social psychology.vol.37.pp.255343.San Diego,CA:Elsevier Academic press

CHE (Council on Higher Education) 2000. Towards a New Education Landscape: Meeting the Equity, Quality and Social Development Imperatives in the $21^{\text {st }}$ Century. Brummeria South Africa: $\mathrm{CHE}$

Chigumadzi. ,M. 2015 .Are interracial relationships possible for South Africans. The Daily Vox. Features

Choudaha, R.2014. 'Universities need to get ready for Indian's high fliers'.No.332.Available at www.universityworldnews.com/article...[accessed 20 October 2015] 
Cinzia,P.S. 2009.'Children Speak about Interethnic and Interracial Friendships in the Classroom'. Lessons for Teachers

Du Plessis, M. 1999. 'Race relations in South African literature since 1990'. South African Children's Literature Unit: University of South Africa

Department of Education (1997). Education White Paper 3: A Programme for the Transformation of Higher Education. General Notice 1196 of 1997. Pretoria

Finchilescu, G. and Tredoux, C. 2008. 'Intergroup contact, social context and racial ecology in South Africa'. In U. Wagner, L. Tropp, G. Finchilescu \& C. Tredoux (Eds.), Improving intergroup relations: Building on the legacy of Thomas $F$. Pettigrew, p.179-94.Malden , MA : Blackwell.

Finchilescu, G. 2005. 'Factors hindering inter-racial contact: The role of metastereotypes'. South African Journal of Psychology35(3).

Finchilescu, G., et.al.2006. 'Testing contact theory in South African: A study of four universities'. Paper presented at the conference, "Contact and Intergroup Relations: 50 Years On", held at Ithala Game Lodge, South Africa, 6-9 July

Fischer, J.,F.2008. 'Does Campus Diversity Promote Friendship Diversity? A Look at interracial Friendships in College' .John Wiley \& Sons.DOI:10.1111/j.15406237.20008.00552.x

Gouws ,A. 2008. ' From Racism to Valuing Diversity'. University World News, Special Africa Edition. Available at http: //www. university worldnews.com/pa per.php? story=20080320160005293>[accessed on 14 September 2015)

Hall, R. E. 1994. 'The bleaching syndrome: Implications of light skin for Hispanic American assimilation'. Hispanic Journal of Behavioral Sciences 16(3): 307- 314.

Hall, R. E. 1990. 'The projected manifestation of aspirations, personal values, and environmental assessment cognates of cutaneo-chroma (skin color) for selected

populations of African Americans.'Dissertations Abstracts International50, 3363A.

Hayward, J. 1989. 'South Africa since 1948'. New York: Bookwright Press 
Hunter, L., and Elias, M. J. 1999. 'Interracial friendships, multicultural sensitivity, and social competence: How are they related?' Journal of Applied Developmental Psychology20:551-573.

"History of KwaZulu-Natal Indian Settlement ...cont. Part 2". Kzn.org.za. Retrieved 2011-11-06.

Manzo, K.,A. 1996. 'Creating Boundaries; The politics of Race and Nation'.

Mukherji, A. ( 2011). 'Durban largest 'Indian' city outside India'. The Times of India.

Mojapelo-Batka, E.M. (2008). Interracial couples within South African context: Experiences, Perceptions and Challenges. Unpublished PhD Thesis. University of South Africa

Moguerane ,K.2007. ' Post-apartheid politics of integration at a residential student community in SouthAfrica: A case study on Campus'. African Sociological Review 11(2): 42-63.

Morrow, S.2008. 'Race, redress and historically Black universities'. In: A Habib, K Bentley (Eds.): Racial Redress and Citizenship in South Africa. Cape Town: HSRC Press, pp. 263-280

National Symbols and Heritage. 2009.Available at sahistory.org.za

Pattman, R.( 2010). 'Investigating 'race' and social cohesion at the University of Kwazulu-Natal'. South African Journal of Higher Education24(6): 963-97 1

Pettigrew, T. F. 1997. 'Generalized intergroup contact effects on prejudice'. Personality and Social Psychology Bulletin, 23(93):173-185.

Race, Ethnicity and Language in South Africa .World ... Available at https://welections.wordpress.com/...south-african.../race-ethnicity-and-lan...

Seekings., J.2008. 'The continuing salience of race: Discrimination and diversity in South Africa'. Journalof Contemporary African Studies26(1): 1-25

Statistics on Post-School Education and Training in South Africa: 2011/ 2011 
Steinitz, V. A., and Solomon, E. R. 1986. ' Starting out: class and community in the lives of working class youth' . Philadelphia: Temple University Press

Stumpf .,R. 2013. 'National and Institutional Change and System and Institutional Performance Indicators'. Paper presented at Higher Education Transformation Colloquium in Bloemfontein, at the University of the Free State, Bloemfontein South Africa, 6 - 8 May 2013

Tatum, B. D. 1992. 'Talking about race, learning about racism: An application of racial identity development theory in the classroom'. Harvard Educational Review $6: 1-24$

Tredoux, C. G., and Finchilescu, G. 2007. ' The contact hypothesis and intergroup relations 50 years on: Introduction to the special issue'. South African Journal of Psychology37(4), 667-678

Tropp, L. R. 2003. 'The psychological impact of prejudice: Implications for intergroup contact'. Group Processes and Intergroup Relations6 pp. 131-149.

William R, and Prairie V.2004. 'The Perceptions of College Students About Interracial Relationships'

Wikipedia(2015).Indians in South Africa

Zirkel 2008. 'The influence of multicultural educational practices on student outcomes and intergroup relations'. Teachers College Record, p.110

Recebido: 18 jan. 2017.

Aprovado: 22 mai. 2017

DOI: $10.3895 /$ rbpd.v6n3.5786

Como citar: ELIZABETH, O. A.; UMOH, S. U. Study experience of Indian students and inter-racil relations at

the University of Kwazulu-Natal. R. bras. Planej. Desenv.,Curitiba, v. 6, n. 3, p. 506-517, set./dez. 2017.

Disponível em: <https://periodicos.utfpr.edu.br/rbpd>. Acesso em: XXX.

Correspondência:

Oyewo Adetola Elizabeth

King George V Ave, Glenwood, Durban, 4041, África do Sul

Direito autoral: Este artigo está licenciado sob os termos da Licença CreativeCommons-Atribuição 4.0

Internacional.

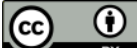

